JAMP: Jurnal Adminitrasi dan Manajemen Pendidikan Volume 1 Nomor 2 Juni 2018, Hal : 132-138

Tersedia Online di http://journal2.um.ac.id/index.php/jamp/ ISSN $x x x x-x x x x$ (online)

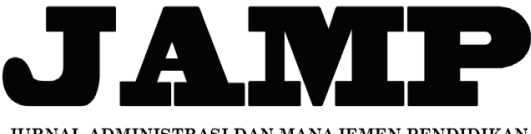

JURNAL ADMINISTRASI DAN MANAJEMEN PENDIDIKAN

\title{
MANAJEMEN EKSTRAKURIKULER ECO SMART PROGRAM BANK SAMPAH DALAM MEMBERIKAN KONTRIBUSI PEMBAYARAN SUMBANGAN PENYELENGGARAAN PENDIDIKAN
}

\author{
Lina Apriliani \\ Ali Imron \\ Imron Arifin \\ E-mail : linaapriliani91@gmail.com \\ Universitas Negeri Malang, Jl. Semarang No. 5 Malang 65145
}

\begin{abstract}
The main objective of research to discribe about (1) the process of implementation of extracurricular Eco Smart trash management program for the financing of SPP, (2) the process of involvement of learners in the extracurricular Eco Smart trash bank program, (3) organizing in the trash bank management for the financing of SPP, (4) from parents and school committees in managing trash banks. This research used the qualitative approach with case study. The result of this study indicate the (1) the extracurricular implementation of the Eco Smart trash bank program includes creating a program of trash disposal, making online trash bank, paying tuition fees from trash bank, paying SPP by trash bank (2) the learners as full participants in trush bank management, (3) the organizations are formed the extracurricular Eco Smart delegated in managing trash banks, (4) support from school committees and parents of learners is motivational support and give some thought for development trash banks in SMK Negeri 6 Malang.
\end{abstract}

Keyword: waste bank, financing of SPP, extracurricular.

\begin{abstract}
Abstrak: Penelitian ini bertujuan untuk mendeskripsikan (1) proses pelaksanaan dari esktrakurikuler Eco Smart program pengelolaan sampah untuk pembiayaan SPP, (2) proses keterlibatan peserta didik dalam ekstrakurikuler Eco Smart program bank sampah, 3) pengorganisasian dalam pengelolaan bank sampah untuk membayar SPP, 4) bentuk dukungan dari orangtua dan komite sekolah dalam mengelola bank sampah. Penelitian ini menggunakan pendekatan kualitatif, dengan rancangan penelitian studi kasus. Hasil dari penelitian ini (1) proses pelaksanaan ekstrakurikuler Eco Smart program bank sampah meliputi membuat program sidak sampah, membuat bank sampah online, membayar SPP dari bank sampah, membayar biaya pendidikan dari bank sampah (2) peserta berperan penuh dalam pengelolaan bank sampah, (3) pengorganisasian terbentuk dari ekstrakurikuler Eco Smart yang di delegasikan mengelola bank sampah, (4) dukungan dari komite sekolah dan orang tua peserta didik adalah dukungan motivasi dan ide fikiran untuk mengembangkan bank sampah SMK Negeri 6 Malang.
\end{abstract}

Kata kunci: bank sampah, pembayaran SPP, Ekstrakurikuler.

Sekolah merupakan sebuah lembaga pendidikan yang mana menyelenggakan proses belajar dan mengajar, adanya interaksi guru dan peserta didik guna mengembangkan kemampuan yang dimiliki oleh peserta didik. Selain proses belajar dan mengajar sekolah juga menyelenggarakan kegiatan di luar jam kegiatan belajar dan mengajar dengan pendamping ahli di bidangnya. Kegiatan ini sering disebut ekstrakurikuler, kegiatan ekstrakurikuler ini biasa diselenggarakan di satuan pendidikan guna memberikan pelayanan kepada peserta didik untuk mengembangkan kemampuannya selain di bidang akademik. Meningkatkan 
kemampuan peserta didik dengan sekolah membuat penyusunan program guna memberikan wadah bagi peserta didik untuk mengembangkan dirinya sehingga visi dan misi sekolah tercapai, sebagaimana yang dijelaskan oleh Imron (2011) penyusunan program adalah suatu aktivitas yang bermaksud memilih kegiatan-kegiatan yang sudah diitentifikasi sesuai dengan langkah kebijakan.

Pengembangan minat dan bakat banyak yang dapat dilakukan, salah satunya dengan memberikan tentang pedidikan mencitai lingkungan. Dengan peduli lingkungan maka kesadaran peserta didik akan pentingnya menjaga alam akan sedikit mengurangi degradasi alam pada saat ini. Salah satunya dengan peduli sampah, seperti yang kita ketahui sampah akan selalu tidak jauh dari kehidupan kita setiap hari. Pengelolaan sampah yang kurang maksimal menimbulkan banyak sekali problema. Jika mendengar kata sampah, pasti yang terlintas dalam pikiran kita adalah setumpuk limbah yang menimbulkan aroma yang kurang sedap. Sampah diartikan sebagai material sisa yang dianggap tidak diharapkan setelah berakhirnya suatu proses dari sebuah produksi. Dalam proses alam sebenarnya tidak ada konsep sampah, yang ada hanya saja produk-produk yang dihasilkan setelah dan selama proses alam itu berlangsung.

Sampah biasanya jarang untuk dikelola oleh lembaga pendidikan, namun berbeda dengan salah satu Sekolah Menengah Kejuruan (SMK) Negeri 6 Malang, sekolah ini memiliki keunikan yang mungkin tidak dimiliki oleh sekolah lain di Kota Malang, hal ini selaras dengan visi dari sekolah tersebut yaitu terwujudnya lulusan yang unggul dalam iman dan taqwa, ilmu dan teknologi, karakter, wirausaha, mampu melestarikan lingkungan, dan siap bersaing di era global. Sampah-sampah yang tidak bermanfaat ini justru dimanfaatkan oleh peserta didik SMKN 6 Malang sebagai alat untuk membayar SPP yang dibayarkan setiap bulannya. Besarnya nominal SPP di sekolah ini yaitu sebesar Rp.200.000-, per individu menurut keteragan dari hasil wawancara kepada Bapak Sulaiman selaku pendiri ekstrakurikuler Eco Smart di SMK Negeri 6 Malang.

Ekstrakurikuler Eco Smart menjadi salah satu unggulan sekolah yang satu-satunya di Kota Malang sehingga dapat dijadikan promosi sekolah untuk menarik peserta didik baru. Kegiatan ini dikelola dengan baik oleh siswa sebagai eksekutor maka kegiatan bank sampah sebagai alat untuk membayar SPP diwadahi dalam bentuk ekstrakurikuler Eco Smart. Kegiatan ini di maksudkan untuk memeberikan pelajaran kepada peserta didik untuk tidak bergantung pada bantuan dari pemerintah dan mengembangkan potensi yang dimiliki peserta didik, sebagaimana yang telah dijelaskan pada Permendikbud nomor 81A tahun 2013, menjelaskan bahwa potensi peserta didik dapat diwujudkan melalui kegiatan ekstrakurikuler yang merupakan salah satu kegiatan dalam program kurikuler. Kegiatan ekstrakurikuler tersebut adalah program kurikuler yang alokasi waktunya tidak ditetapkan dalam kurikulum.

Prestasi yang diraih oleh SMK Negeri 6 Malang dalam bidang lingkungan adalah menraih Adiwiyata mandiri pada tahun 2012. Juara 3 (tiga) Green School Festival (GSF) tahun 2014, Juara 1 (satu) GSF tahun 2015, Juara 1 (satu) GSF tahun 2016, pada tahun 2017 bekerjasama dengan United States Agency for International (USAID) Amerika Serikat bidang Adaptasi Perubahan Iklim dan Ketangguhan (APIK). SMK Negeri 6 Malang sekolah yang berbasis teknik ini memiliki ciri khas, yaitu dapat memperdayakan sampah sebagai alat untuk membayar SPP dan memiliki bank sampah, sehingga menarik peneliti untuk mengungkapkan fakta seperti manajemen pengelolaan ekstrakurikuler Eco Smart program bank sampah sebagai alat untuk membayar SPP.

\section{METODE}

Penelitian ini menggunakan pendekatan kualitatif. Teknik pengumpulan data yang digunakan dalam penelitian ini adalah wawancara, dokumentasi, dan observasi. Menurut Sugiyono (2013) "penelitian kualitatif adalah metode penelitian yang digunakan untuk meneliti pada kondisi obyek ilmiah, dimana peneliti adalah sebagai instrument kunci". Peneliti menggunakan metode penelitian kualitatif karena ingin menggali informasi mendalam terkait bank sampah SMK Negeri 6 Malang. Jenis penelitian yang digunakan yaitu penelitian studi kasus, yangmana peneliti ingin mengetahui dan menemukan fakta tentang manajemen bank sampah untuk membayar SPP. Menurut Bugin (2008), studi kasus adalah suatu "studi yang bersifat komprehensif, intens, rinci dan mendalam serta lebih diarahkan sebagai upaya menelan masalah-masalah atau fenomena yang bersifat kontemporer, kekinian". Adapun objek dari 
penelitian ini meliputi manusia, peristiwa, latar, serta dokumen.

Peneliti dalam penelitian ini bertindak sebagai intrument kunci yang mana secara langsung terjun kelapakan dalam mengumpulkan data-data. Sumber data penelitian ini meliputi Pembina ekstrakurikuler, Ketua atau wakil ekstrakurikuler, pengurus bank sampah, direktur bank sampah, dan peserta didik SMK Negeri 6 Malang. Analisis data yang diperoleh dari lapangan dan setelah di lapangan, kemudian data-data tersebut direduksi, dirangkum dan disesuaikan dengan fokus penelitian. Kemudian dilakukan verifikasi data dengan membuat kesimpulan berdasarkan data yang direduksi. Terakhir pengecekan keabsahan data penelitian ini menggunakan triangulasi sumber data dan metode.

\section{HASIL}

\section{Proses Manajemen ekstrakurikuler Eco Smart program bank sampah dalam membayar SPP di SMK Negeri 6 Malang}

Proses manajemen ekstrakurikuler Eco Smart program bank sampah, meliputi nasabah bank sampah melakukan penyetoran sampah ke bank sampah daur ulang dan tidak terbatas jumlah sampah yang dibawa ke bengkel Eco Smart. Kemudian oleh petugas yang berjaga dilakukan penimbangan dan pencatatan dalam masing-masing buku tabungan nasabah. Nasabah dari bank sampah SMK Negeri 6 Malang terdiri dari peserta didik, guru, staff sekolah, dan orang tua peserta didik. Kemudian setalah dilakukan pencatatan oleh petugas maka sampah yang telah dicatat akan dipilah dan dikelompokkan sesuai dengan jenisnya. Sampah dari SMK Negeri 6 Malang kemudian di angkut ke bank sampah Malang untuk di cairkan menjadi uang. Jika uang sudah cair maka nasabah (peserta didik) mengkonfirmasi kepada petugas membayar SPP menggunakan sampah. Besar SPP di SMK Negeri 6 Malang Rp. 150.000,00 Rp. 200.000,00. Pembayaran di bank sampah SMK Negeri 6 Malang dapat dilakukan dengan 2 cara yaitu dengan datang langsung ke bengkel Eco Smart dan dilakukan secara online.

\section{Peran peserta didik dalam pengelolaan ekstrakurikuler Eco Smart program bank sampah}

Peran peserta didik dalam pengelolaan bank sampah mendominasi. Karena seluruh proses manajemen bank sampah mulai dari menerima, menimbang, memilah, merekap hingga pendistribusian merupakan tanggungjawab peserta didik sebagai pengurus bank sampah. Sedangkan peserta didik yang lainnya dapat menjadi nasabah aktif dari bank sampah SMK Negeri 6 Malang.

\section{Pengorganisasian Eco Smart program bank sampah}

Pengorganisasian bank sampah merupakan bagian dari ekstrakurikuler Eco Smart, yang memiliki program bank sampah. Jadi pengurus dari bank sampah diambil dari pengurus ekstrakurikuler Eco Smart yang diberikan mandat untuk mengelola bank sampah. Tugas bank sampah diberikan kepada enam orang anak yang didelegasikan untuk mengelola bank sampah, namun dalam pelaksanaanya enam orang yang diberi tugas tersebut dibantu dengan pengurus ekstrakurikuler yang lain. Pembagian tugas telah dibagi dalam lima bidang, yaitu bidang tabungan / pembukuan, penimbangan dan pencatatan, pemilihan, kerjasama, dan pendistribusian.

Dalam melaksanakan perekrutan pengurus baru dilaksanakan tes yang secara langsung diambil alih oleh pembina ekstrakurikuler, tindakan tersebut dilakukan guna menyeleksi calon pengurus yang benarbenar berminat dan bersemangat untuk menjalankan tugas. Kendala yang sering menghambat kegiatan bank sampah adalah kurangnya waktu yang tersedia dan sumber daya manusia yang kurang, sehingga untuk mengatasi kendala tersebut maka mengambil solusi untuk menambah sumber daya manusia dari petugas kebersihan.

\section{Dukungan komite sekolah kepada ekstrakurikuler Eco Smart program bank sampah}

Dukungan komite sekolah dalam menyelenggarakan bank sampah tampak memberikan dukungan kepada peserta didik yang menjadi petugas bank sampah dan peserta didik lainnya untuk giat menabung sampah, sebagaiamana dalam penelitian bahwa dengan menabung sampah akan memberikan sedikit keringanan dalam membayar biaya pendidikan yag relatif mahal. Dukungan ini ditunjukkan seperti dukungan materiil berupa baju kerja petugas bank sampah (PDH) dan dukungan motivasi, baik kepada 
peserta didik sendiri maupun petugas bank sampah yang diambil dari pengurus ekstrakurikuler Eco Smart.

Kemudian dukungan dari orang tua peserta didik juga diberikan kepada bank sampah SMK Negeri 6 Malang. Dukungan dari peserta didik ini ditunjukkan dengan memberikan izin kepada putra-putrinya untuk mengikuti segala bentuk kegiatan. Ide kreatif juga diberikan kepada ekstrakurikuler Eco Smart jika mengikuti lomba. Bentuk dukungan yang terakhir adalah orangtua peserta didik ikut menabung di bank sampah SMK Negeri 6 Malang.

\section{PEMBAHASAN}

\section{Proses Manajemen ekstrakurikuler Eco Smart program bank sampah dalam membayar SPP di SMK Negeri 6 Malang}

Ektrakurikuler merupakan kegiatan peserta didik yang ada di sekolah, yang dilaksanakan diluar jam pelajaran dan dapat dilaksanakan di dalam dan di luar ruangan. Ekstrakurikuler merupakan salah satu usaha manajemen peserta didik sebagaimana menurut Imron (2012) Mengemukakan manajemen peserta didik dapat diartikan sebagai usaha pengaturan peserta didik : mulai dari peserta didik tersebut masuk sekolah sampai mereka lulus. Adapun fungsi manajemen peserta didik menurut Imron (2012) adalah sebagai wahana bagi peserta didik untuk mengembangkan diri seoptimal mungkin, baik yang berkenaan dengan segi-segi indivialitasnya, segi sosial, aspirasi, kebutuhan dan segi-segi potensi peserta didik lainnya.

Cara mengelola bank sampah yang dapat digunakan untuk membayar SPP adalah peserta didik ke sekolah membawa sampah, apapun jenisnya dan tidak dibatasi jumlahnya. Sampah tersebut dibawa ke bengkel Eco Smart dan diserahkan kepada petugas yang berjaga di tempat, kemudian oleh petugas sampah yang telah diterima dari peserta didik di timbang. Setelah diketahui beratnya maka petugas melihat buku pedoman yang di peroleh dari bank sampah Malang sebagai patokan harga. Proses menimbang sampah sudah selesai dan diketahui harga sampahnya maka oleh petugas akan dicatat dalam buku besar untuk rekam pemasukan saldo pesrta didik yang membayar sampah. Selain perekaman buku besar milik Eco Smart juga peserta didik atau nasabah akan diberikan buku kecil guna mencatat saldonya. Saldo yang masuk oleh peserta didik jika sudah memenuhi untuk membayar SPP maka pihak pengelola Eco Smart membarikan informasi kepada bendahara sekolah bahwasannya peserta didik yang bersangkutan membayar SPP menggunakan sampah.

Selain itu sistem pembayaran dikembangkan lebih modern lagi, dengan menggunakan sistem IT. Pembayaran sampah yang disetorkan dari nasabah yang terdiri dari peserta didik dan staff SMK Negeri 6 malang juga berkembang, sekarang orang tua peserta didik dapat menjadi nasabah bank sampah SMK Negeri 6 Malang. Pembayaran sampah berbasis online ini nasabah dapat menginput sendiri sampah yang akan disetorkan berupa berat sampah dan jenis sampah yang dimasukkan dalam data base dan pilihan yang ada dalam sistem, kemudian akan muncul harga sampah dan data tersebut akan dicatat dalam bentuk saldo digital. Sistem ini dimaksudkan untuk mempermudah dalam membayar sampah, serta melatih kejujuran dari nasabah bank sampah SMK Negeri 6 Malang.

Program Bank Sampah yang dimiliki Eco Smart di SMK Negeri 6 Malang ini tidak hanya digunakan untuk membayar SPP saja. Jika ada uang lebih, maka peserta didik ini dapat menggunakan uang tersebut untuk keperluan pendidikan lainnya. Seperti untuk membayar kunjungan industri ke luar kota, membayar buku, dan lain sebagainya. Fakta ini membuktikan bahwa dengan adanya bank sampah akan memberikan keringanan biaya pendidikan, dengan demikian semua komponen tidak akan tergantung dengan program subsidi pendidikan dari pemerintah.

\section{Peran peserta didik dalam pengelolaan ekstrakurikuler Eco Smart program bank sampah}

Kegiatan ekstrakurikuler Eco Smart memiliki program bank sampah untuk membayar SPP. Manajemen pengelolaan bank sampah untuk membayar SPP dikelola oleh peserta didik. Hal tersebut 
sesuai dengan Peraturan Menteri Pendidikan Nasional Republik Indonesia Nomor 39 Tahun 2008 tentang Pembinaan kesiswaan. Kegiatan ekstrakurikuler yang diikuti dan dilaksanakan oleh siswa baik di sekolah maupun diluar sekolah, bertujuan agar siswa dapat memperkaya dan memperluas diri. Program bank sampah untuk membayar SPP yang dibuat oleh ekstrakurikuler Eco Smart di SMK Negeri 6 Malang, terbagi dalam dua peran peserta didik dalam ekstrakurikuler Eco Smart program bank sampah, yaitu peserta didik yang hanya menjadi nasabah bank sampah dan peserta didik yang menjadi pengelola bank sampah SMK Negeri 6 Malang.

Adapun peserta didik yang menjadi pengelola bank sampah SMK Negeri 6 Malang adalah sebagai penerima sampah dari nasabah yang menyetorkan sampah. Sebagai penimbang sampah dari sampah yang diterima, kemudian direkap dalam buku tabungan masing-masing nasabah. Jika sampah sudah penuh maka sampah akan dijual ke bank sampah Malang untuk dicairkan uangnya kemudian didistribusikan kepada nasabah yang hendak mengambil tabungannya. Sedangkan peserta didik lainnya aktif dalam menabung sampah dan ikut mendukung dan turun serta dalam agenda sidak sampah. Dalam pelaksanaannya petugas bank sampah dari peserta didik dibantu oleh petugas kebersihan untuk menyekesaikan tugas mengenai bank sampah.

\section{Pengorganisasian Eco Smart program bank sampah}

Pengorganisasian bank sampah dalam menajalankan tugasnya telah dibagi menjadi lima bagian. Masing-masing bagian memiliki tugas pokok, sehingga manajemen bank sampah berjalan dengan sesuai yang diharapkan. Pembagian tugas dimasing-masing divisi dibagi menjadi lima bagian, yaitu koordinator butu tabungan/Bendahara, koordinator penimbangan dan pencatatan, koordinator pemilihan, koordinator kerjasama, dan koordinator pendistribusian. Masing-masing bidang memiliki tugas dan tanggungjawab yang telah diatur dalam AD/ART beserta jobdesc sehingga dapat mencapai tujuan dengan apa yang telah direncanakan. Sependapat dengan Imron (2011) menjelaskan bahwa manajemen adalah suatu kegiatan yang dilakukan secara bersama-sama oleh dua orang atau lebih yang didasarkan atas aturan tertentu dalam rangka mencapai suatu tujuan.

Sebagaiamana dalam suatu organisasi diperlukan upgrading pengurus guna meneruskan estafet kepengurusan sehingga organisasi tidak berhenti setelah angkatan lama sudah lulus. Dalam reorganisasi kepengurusan ekstrakurikuler Eco Smart melalui seleksi yang ketat, diamana pembina sendiri yang memandu seleksi calon pengurus esktrakurikuler Eco Smart. Jika sudah dinyatakan diterima maka akan dilaksanakan orientasi pengurus baru guna memperkenalkan secara mencalam kepada pengurus baru tentang Eco Smart sehingga dalam melaksanakan tugas akan merasa nyaman, disamping itu juga menciptakan kekeluargaan antar pengurus lainnya.

\section{Dukungan komite sekolah kepada ekstrakurikuler Eco Smart program bank sampah}

Dukungan yang diberikan kepada bank sampah SMK Negeri 6 Malang mendukung penuh ekstrakurikuler Eco Smart program bank sampah. Karena dengan adanya program bank sampah orang tua peserta didik akan merasa terbantu dengan biaya pendidikan. Didukung sekolaah SMK Negeri 6 Malang sekolah yang ber-basic teknik, dimana banyak memerlukan biaya untuk praktek dan kunjungan industri. Dukungan dari komite sekolah adalah dengan memberikan seragam kerja (PDH), dukungan moril dan motivasi agar semangat untuk menjalankan tugas menjadi pengelola bank sampah. Dukungan kepada nasabah bank sampah juga ditunjukkan dengan memberikan motivasi kepada nasabah agar lebih giat lagi menabung sampah. Seperti yang kita ketahui komite sekolah adalah jembatan untuk menyampaikan aspirasi dari masyarakat kepada sekolah, dengan tujuan untuk kearah yang lebih baik lagi tentang sekolah. Hal tersebut sependapat dengan Keputusan Menteri Pendidikan Nasional Nomor 044/U/2002 Tentang Dewan Pendidikan dan Komite Sekolah dalam Benty \& Gunawan (2015) menyatakan bahwa Komite Sekolah adalah badan mandiri yang mewadahi peran serta masyarakat dalam rangka meningkatkan mutu, pemerataan, dan etisiensi pengeloaan pendidikan di satuan pendidikan, baik pada pendidikan prasekolah, jalur pendidikan sekolah maupun jalur pendidikan luar sekolah.

Kemudian dukungan lain dari orang tua peserta didik yang memberikan izin kepada anaknya untuk mengikuti segala kegiatan ekstrakurikuler bank sampah, orang tua peserta didik sudah percaya dengan 
sekolah. hal ini karena strategi dari pembina ekstrakurikuler yang memberikan jaminan positif kepada putra-putri orang tua sehingga orang tua percaya. Selain itu dukungan dari orang tua ditunjukkan dari memberikan idek kreatif setiap mengikuti lomba.

\section{KESIMPULAN DAN SARAN}

\section{Kesimpulan}

Manajemen pelaksanaan ekstrakurikuler Eco Smart program bank sampah dilaksanakan oleh peserta didik SMK Negeri 6 Malang. Dimana salah satu sistem ini menggunaka strategi bank sampah sampah online, tujuannya untuk mempermudah nasabah bank sampah SMK Negeri 6 Malang. Jadi pembayaran sampah dapat dilakukan 2 cara yaitu dengan manual datang langsung ke bengkel Eco Smart SMK Negeri 6 Malang dan dilakukan dengan online, petugas mengabil sampah ditempat nasabah menuliskan alamat didalam pesan singkat. Kemuadian kegiatan yang dilakukan bank sampah menimbang, membukukan, memilih sampah, serta mendistribusikan hasil tabungan kepada nasabah. Jika peserta didik berkenan untuk membayar SPP maka konfirmasi kepada petugas bank sampah, kemudian petugas mengkonfrimasi kepada bendahara sekolah. Disamping itu hasil bank sampah tidak hanya digunakan untuk membayar SPP saja, hasil dari bank sampah juga sebagian dapat digunakan untuk keperluan pendidikan lainnya seperti keperluan wisuda, kunjungan industri.

Peran peserta didik manajemen ekstrakurikuler Eco Smart untuk membayar SPP pengelola penuh bank sampah SMK Negeri 6 Malang. Beberapa peserta didik yang ditugaskan untuk mengelola bank sampah yang diambil dari kepengurusan ekstrakurikuler Eco Smart. Namun dalam pelaksanaanya peserta didik juga dibantu oleh petugas kebersihan untuk menyelesaikan tugas pengelolaan bank sampah.

Struktur organisasi bank sampah ini dibawah kepengurusan ekstrakurikuler Eco Smart karena bank sampah ini merupakan program dari ekstrakurikuler tersebut. Sehingga pelaksana dari bank sampah diambil dari sebgaian kecil dari pengurus ekstrakurikuler Eco Smart. Pembagian tugas sudah dibagi jelas dalam setiap sub divisi bank sampah sehingga manajemen bank sampah SMK Negeri 6 Malang berjalan sesuai dengan tupoksinya masing-masing. Orientasi pengurus baru dilaksanakan di dua tempat berbeda yang pertama di dalam sekolah dan yang kedua dilaksnaakn di alam. Hambatan dari bank sampah ini adalah waktu yang minimal dan SDM yang terbatas, sehingga menambah SDM dari petugas kebersihan untuk menyelesaikan tugas bank sampah.

Dukungan penuh dari orang tua peserta didik yang memberikan respon positif kepada kegiatan bank sampah. Faktanya orang tua peserta didik ikut menabung sampah untuk meringankan beban biaya pendidikan. Dukungan dari komite sekolah adalah bentuk dukungan berupa motivasi kepada peserta didik untuk menabung sampah sehingga dapat meringankan beban biaya pendidikan.

\section{Saran}

Berdasarkan kesimpulan penelitian, direkomendasikan kepada. pertama, Bagi Kepala sekolah SMK Negeri 6 Malang diharapkan terus mendukung dan menfasilitasi kegiatan ekstrakurikuler Eco Smart terutama program bank sampah untuk membayar SPP. Karena dengan adanya program bank sampah ini akan sedikit membantu beban biaya pendidikan yang ditanggungkan kepada masing-masing peserta didik. Kepala sekolah diharapkan terus menjalin kerjasama yang baik dengan komite sekolah dan organisasi orang tua peserta didik dalam meningkatkan efisiensi bank sampah SMK Negeri 6 Malang. Kedua, Bagi Guru Pembina Ekstrakurikuler Eco Smart untuk terus membuat inovasi perbaikan bank sampah SMK Negeri 6 Malang sebagia alat untuk membayar biaya pendidikan, dan memperluas serta mengadakan ekstrakurikuler bank sampah di sekolah lain yang belum melaksanakan kegiatan ekstrakurikuler Eco Smart program bank sampah ini. Dengan program bank sampah diharapkan biaya pendidikan yang relatif mahal akan sedikit terbantu dengan adanya bank sampah. Sehingga maindset pendidikan yang mahal akan hilang.

Ketiga, Bagi peserta didik dapat digunakan sebagai bahan pertimbangan dalam memaksimalkan kesempatan untuk membantu beban biaya pendidikan yang masih ditanggung oleh orang tua. Dan 
diharapkan dengan menabung sampah untuk dapat dijadikan sebagai motivasi instrinsik peserta didik, Serta belajar untuk menjadi mandiri dengan menjadi nasabah bank sampah. Keempat, Bagi sekolah lain, diharapkan dapat mencontoh tentang bank sampah sehingga dapat dijadikan solusi bagi sekolah lain untuk mendapatkan tambahan biaya pendidikan. Dengan demikian akan menciptakan peserta didik yang peduli lingkungan dan melatih kemandirian peserta didik.

\section{DAFTAR RUJUKAN}

Benty \& Gunawan. 2015. Manajemen Hubungan Dan Masyarakat . Malang: UM Press

Bungin, B. 2008. Metodologi Penelitian Kualitatif. Jakarta: PT. Raja Grafindo Persada

Imron, A. 2012. Kebijaksanaan Pendidikan Di Indonesia. Jakarta: Bumi Aksara

Imron, A.2011. Manajemen Peserta Didik Berbasis Sekolah. Jakarta: Bumi Aksara

Peraturan Mentri Pendidikan dan Kebudayaan RI Nomor 81A Tahun 2013 tentang Implementasi Kurikulum: Pedoman Kegiatan Ekstrakurikuler.

Peraturan Mentri Pendidikan Nasional Republik Indonesia Nomor 39 Tahun 2008 (Permendiknas RI No. 39.2008) pasal 3 tentang Pembinaan Kesiswaan.

Sugiyono. 2013. Metode Penelitian Pendidikan Pendekatan Kuantitatif, Kualitatif dan R\&D. Bandung: Angkasa Bandung. 